\title{
A Review of the Effects of Climate Change on Chelonians
}

\author{
Christopher J. Butler \\ Department of Biology, University of Central Oklahoma, Edmond, OK 73020, USA; cbutler11@uco.edu
}

Received: 11 July 2019; Accepted: 13 August 2019; Published: 16 August 2019

\begin{abstract}
Climate change is occurring at an unprecedented rate and has begun to modify the distribution and phenology of organisms worldwide. Chelonians are expected to be particularly vulnerable due to limited dispersal capabilities as well as widespread temperature-dependent sex determination. The number of papers published about the effects of climate change on turtles has increased exponentially over the last decade; here, I review the data from peer-reviewed publications to assess the likely impacts of climate change on individuals, populations, and communities. Based upon these studies future research should focus on: (1) Individual responses to climate change, particularly with respect to thermal biology, phenology, and microhabitat selection; (2) improving species distribution models by incorporating fine-scale environmental variables as well as physiological processes; (3) identifying the consequences of skewed sex ratios; and (4) assessments of community resilience and the development of methods to mitigate climate change impacts. Although detailed management recommendations are not possible at this point, careful consideration should be given regarding how to manage low vagility species as habitats shift poleward. In the worst-case scenario, proactive management may be required in order to ensure that widespread losses do not occur.
\end{abstract}

Keywords: chelonian; turtle; tortoise; climate change; species distribution model; ecological niche model; temperature-dependent sex determination

\section{Introduction}

Anthropogenic climate change has numerous effects on biological communities, with many studies demonstrating ongoing changes in phenology, distribution, and community interactions [1-7]. In addition, anthropogenic climate change can reduce the amount of suitable habitat within the range of a species and thus increase the risk of extinction [8,9]. Climate change has been identified as one of the major threats to reptile populations [10]; the persistence of species may depend not only on the ultimate persistence of the climate, but also on the ability to keep pace with moving climates [11].

Turtles are one of the most threatened groups of vertebrates. According to the International Union for Conservation of Nature (IUCN) Red List [12], approximately $62.8 \%$ of chelonians (162 of 258 species) are either critically endangered $(19.4 \% ; n=50)$, endangered $(17.4 \% ; n=45)$ or vulnerable $(30.0 \%$; $n=65)$. The threats facing turtles are varied and include habitat loss, overexploitation, predation, invasive species, diseases, and climate change [10,13]. Poikilothermic animals, including turtles, may be particularly susceptible to the effects of anthropogenic climate change [14].

The possible effects of climate change on chelonians are varied and include potential skews in sex ratios [15], alteration of existing habitat [6,16], loss of suitable habitat [17], and extinction [18]. In addition, turtles and tortoises have limited vagility and may not be able to keep pace with forecasted climatic changes [10]. The impacts of climate change may vary depending upon the life-history stage; many aspects of chelonian embryonic development are influenced by hydrology and temperature while they are in the nest [19]. Anthropogenic climate change could affect individual growth rates [20], fecundity [21], reproductive phenology [22], sex ratios via temperature-dependent 
sex determination [15], and predation rates [23,24]. Although turtles have survived previous periods of climate change, the existing rate of change is far more rapid and turtles may not be able to respond in time, due in part to their long generation times [25].

Much of the existing research on climate change and chelonians has focused on the effects of climate change on marine turtles. Although the seven species of sea turtle (Chelonia mydas, Caretta caretta, Eretmochelys imbricata, Dermochelyis coriacea, Lepidochelys kempii, L. olivacea, and Natator depressus) represent approximately only $2 \%$ of the existing chelonian species [12], $52.1 \%$ of published papers on turtles and climate change between 1991 and 2017 focused on sea turtles $(n=335$ and 643 respectively; Figure 1). Hawkes et al. [25,26] provided a review of existing papers on sea turtles and climate change. To date, however, there has not been a review of the effects of climate change on freshwater or terrestrial chelonians. Additionally, the number of papers published on climate change effects on turtles and tortoises have increased more than four-fold since the publication of this review (Figure 1), so an updated, comprehensive review of data published on the existing and predicted effects of climate change on sea turtles, as well as freshwater and terrestrial chelonians, is warranted.

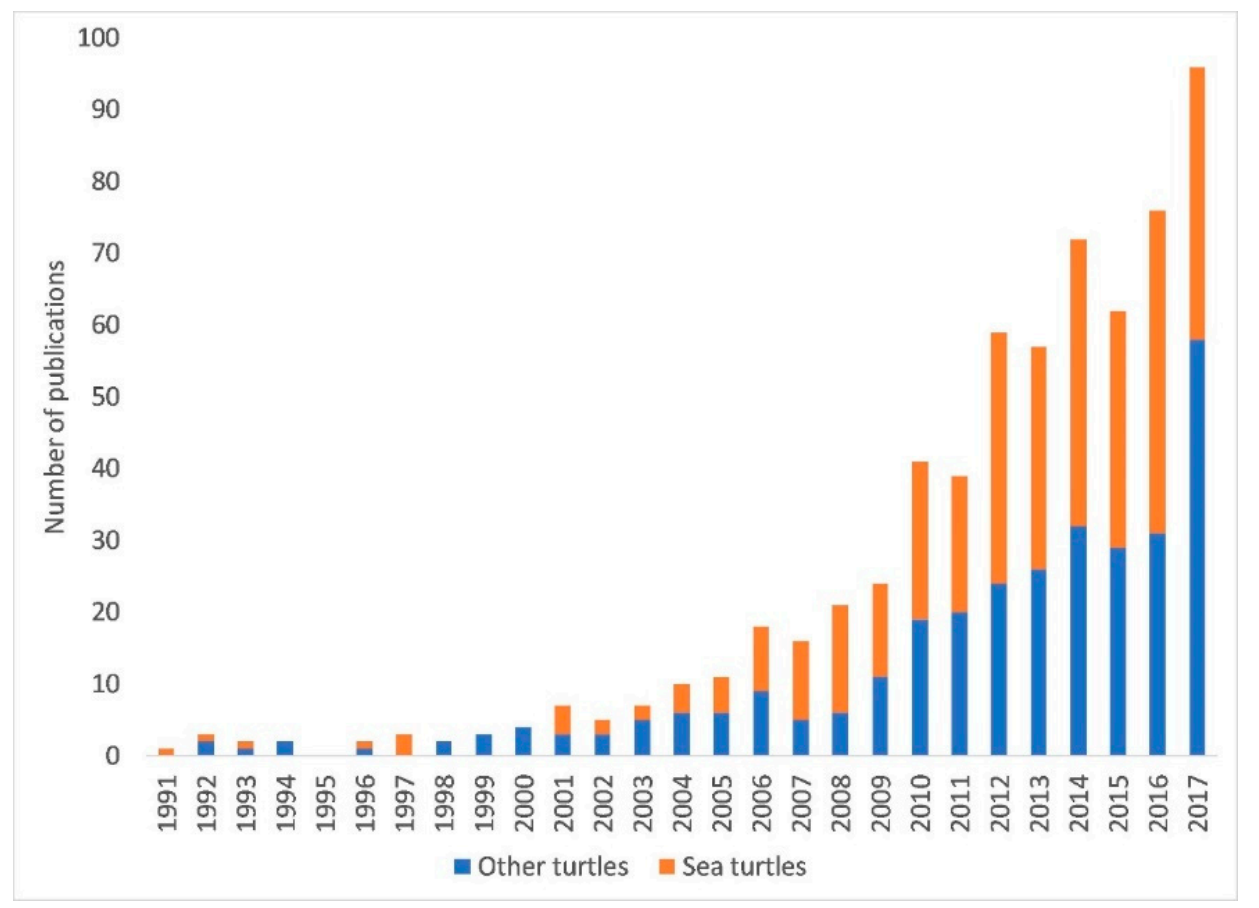

Figure 1. The number of published papers related to climate change and chelonians has increased substantially during the 21st century. This figure summarizes the number of published studies per year (resulting from an ISI (Institute for Scientific Information) Web of Science search on 8 August 2019) containing the search terms "turtles OR tortoises OR chelonian" and "climate change or global warming", as well as the search terms "sea turtle OR Chelonia OR Caretta OR Eretmochelys OR Dermochelyis OR Lepidochelys OR Natator" and "climate change or global warming".

\section{Current Effects}

A hierarchical classification of ecology, from smallest to largest, includes cells, organisms, populations, communities, ecosystems, landscapes, biomes, and the biosphere, although other classification schemes have been proposed [27]. However, most ecological studies focus on organisms, populations, and communities [28]. Anthropogenic climate change could conceivably affect each of these levels, with effects on individuals leading to changes in populations, which in turn could lead to changes in communities. There have been numerous studies on the effects of climate change for each of these levels in a variety of organisms over the past three decades, with many of the studies exploring the potential effects of climate change during the second half of the 21st century. There have also been 
a few studies exploring the current effects of climate change on chelonians. The following summarizes research showing how climate change currently affects individuals, populations, and communities.

\subsection{Individuals}

Climate change could conceivably modify resource availability, reducing or changing the prey base and affecting individual growth rates or survivorship. In addition, phenotypic and behavioral plasticity could also potentially ameliorate or mitigate the effects of climate change. For example, an individual could modify the date of egg-laying in response to warmer temperatures [29]. However, there have been few studies that explicitly looked at the effects of climate change on individual turtles. For example, studies exploring how climate change affects the prey base for individual chelonians are largely lacking. One notable exception is a study that found that a heat wave in 2010/2011 in Australia caused a $90 \%$ reduction in the amount of sea grass in some areas, which was linked to reduced health in green sea turtles for up to two years following the event [30].

There are several studies about how temperatures affect adult sea turtles. For example, wintertime dive duration in loggerhead turtles is inversely related to sea surface temperatures, and they may adopt a "sit-and-wait" strategy with limited surfacing during periods of cold temperatures [31]. Some sea turtle species will also make seasonal trips to forage in areas that are only thermally suitable on a seasonal basis $[32,33]$. In addition, if water temperatures drop below $10^{\circ} \mathrm{C}$, sea turtles may experience "cold stunning", which can be lethal [34]. In contrast, there is a paucity of studies examining how changes in temperature affect adult individuals of freshwater or terrestrial turtles. Painted turtles (Chrysemys picta) exposed to novel environmental conditions did not display a measurable stress response, nor did they exhibit a depressed immune response when transplanted to a novel climatic environment [35].

Of the existing research regarding the effects of climate change on individuals, the majority of effort has focused on nest-site selection and its effects on egg development. Nest-site selection influences the thermal environment for the developing embryos, which can affect embryo survivorship and the sex of the offspring (e.g., [36-38]). Chinese softshell turtles (Pelodiscus sinensis) exhibited only a 73.7\% hatching rate when incubated at $34^{\circ} \mathrm{C}$, considerably lower than the $81.7-96.9 \%$ hatching rate when they were incubated at $24-32{ }^{\circ} \mathrm{C}$ [20]. In addition, it was also suggested that developing embryos can reposition themselves within the egg to take advantage of warmer temperatures [39,40]. However, this suggestion has been contested, as diurnal shifts in temperature may occur too rapidly for embryos to respond [41]. Additionally, the rapid growth of embryos means that internal egg space rapidly diminishes, and muscle development is insufficient during the resulting narrow temporal window for behavioral thermoregulation [42].

Temperature and precipitation can affect growth rates of hatchling chelonians, and climate change could potentially negatively impact these rates [43]. For example, warmer temperatures can influence post-hatching growth rates [44], with warmer temperatures resulting in slower growth for some species $[45,46]$. In addition, climate change may also affect hatchling survivorship. For instance, red-eared sliders (Trachemys scripta) in Illinois exhibited a negative relationship between mean ambient temperature and dry residual yolk mass, suggesting that warmer temperatures reduce the energy stores available to neonates of this species, which may in turn negatively affect hatchling fitness [47]. However, warmer conditions may be beneficial to hatchling survivorship near the poleward edge of their range. Many turtle species engage in delayed emergence, where hatchlings overwinter in the nest [48]. Greater survivorship in hatchling painted turtles was linked to overwinter temperatures, which were warmer in Indiana than in Nebraska [49].

\subsection{Populations}

Population-level impacts of climate change could include expansion or contraction of distributions, changes in sex ratios, changes in survivorship, and increases or decreases in fecundity and recruitment. Additionally, anthropogenic climate change could reduce access to nesting substrates. 
Phenological changes, such as the timing of reproduction, could also potentially occur. There are few published reports that have linked ongoing changes in chelonian distribution to climate change. At a fine scale, there was a slight northward shift in loggerhead sea turtle (Caretta caretta) nest placement along Melbourne Beach, Florida [50]. At the regional scale, the Mediterranean stripe-necked terrapin (Mauremys leprosa) of the Iberian peninsula expanded into inland areas over the past several decades, and concomitantly occupied higher altitudes as well [51]. Finally, Kemp's ridley historically nested along approximately $1000 \mathrm{~km}$ of beach in Mexico, but have now been observed laying eggs as far away as the Atlantic coast of Florida [52,53], more than $1700 \mathrm{~km}$ distant, due to warmer conditions. Additionally, the distribution of the leatherback sea turtle is tied to the $15^{\circ} \mathrm{C}$ isotherm in the North Atlantic, and the summer position of this isotherm has shifted north by more than $330 \mathrm{~km} \mathrm{[54].}$

Climate change could conceivably affect temperature-dependent sex determination (TSD), although the pattern of TSD in turtles is variable [55]; not all species exhibit TSD [56], as some species exhibit genetic sex determination [57]. There are three types of TSD: (1) Low temperatures result in females, while high temperatures result in males, abbreviated FM; (2) low temperatures produce males while high temperatures produce females, abbreviated MF; and (3) low temperatures result in females, medium temperatures result in males, and high temperatures result in females, abbreviated FMF [58]. Some turtle species exhibit MF, while others exhibit FMF; no turtle species exhibit FM [55]. The pivotal temperature is the temperature at which the ratio of male to female turtles is 1:1 for species that exhibit TSD [59], and some species exhibit geographical variation in the pivotal temperature between male and female offspring [60]. Oddly, there are apparently no published studies confirming that hatchlings identified as one sex, as determined by incubation temperatures, are indeed that sex at sexual maturity [61]. Nonetheless, warmer temperatures may exceed the pivotal temperature and are most frequently linked with an increase in feminization in turtles that exhibit TSD. For example, green sea turtles reproducing in the northern Great Barrier reef have become extremely female-biased during the past two decades and this population is at risk of becoming completely feminized in the near future [62]. In the Caribbean, green sea turtles, hawksbill, and leatherback turtles have had female-biased hatchling sex ratios for at least the last century, and it is anticipated that climate change will further exacerbate this skew [63].

Potential feminization is also a cause for concern in freshwater turtles. For example, ambient air temperature during July affected sex ratios of hatchling painted turtles [64]. However, not all studies found that warmer temperatures led to a female bias. Of ten species studied at Point Pelee National Park in Ontario in Canada, only one species exhibited a significant change in sex ratios since 1972, as red-eared sliders became more male-biased over time even as temperatures increased [13]. A similar trend was reported in another population as well [65]. Warming temperatures led to a longer egg-laying season of this species in Illinois, resulting in females laying an additional clutch of eggs when soil temperatures were relatively cool, resulting in a gradual male bias [65]. Additionally, although the ongoing effects of existing climate change on TSD are a cause for concern, land use change is currently more important in determining sex ratios in the Blanding's turtle (Emydoidea blandingii) than ongoing climate change [66].

There is also evidence that temperatures play a role in seasonal movements. Hawksbill sea turtles in the Persian/Arabian Gulf temporarily emigrate from the area during the hottest summer months of June through August when the sea surface temperature averages $33.5^{\circ} \mathrm{C}$ and return when temperatures begin to cool down during September and October [67]. Another study demonstrated that painted turtles in Illinois initiated nests sooner during years when ice disappeared earlier [68]. Similarly, the nesting phenology of six genera of freshwater turtles (Chelydra, Chrysemys, Kinosternon, Malaclemys, Sternotherus, and Trachemys) tends to correlate with temperatures approximately one month before egg-laying begins, with 11 of the 16 studied populations showing advances in nesting phenology [69].

There is also evidence that increasing temperatures impact abundance, nesting phenology, and intervals between successive nesting seasons for hawksbill turtles in the southern Gulf of Mexico [70]. For example, sea surface temperatures (SSTs) for Pacific loggerhead foraging areas 
have steadily increased since 1955 and nesting abundance at rookeries declined as temperatures increased [71]. However, the effects of rising temperatures on the reproductive phenology of sea turtles is mixed. Mazaris et al. [72] found that warmer sea surface temperatures in the foraging ground triggered earlier egg-laying, as did Patel et al. [73]. In contrast, Neeman et al. [74] found that warmer sea surface temperatures at the foraging grounds led to later nesting in leatherback sea turtles. It was also suggested that the local conditions at the nesting grounds were more important than conditions on the foraging grounds [72].

There is a paucity of studies that link ongoing climate change with changes in fecundity. In many temperate turtle species, follicular development begins in the fall, is suspended during the winter, and resumes during the spring, although the relative amount of development during autumn and spring varies between species [75]. Nearly all follicular development in snapping turtles (Chelydra serpentina) occurs during autumn, and warmer temperatures during this season have been linked to increases in egg mass, clutch mass, and clutch size [76]. Climate change can also affect fecundity by changing the accessibility of suitable nesting substrates. Sand bank availability in the Trombetas Reserve in Brazil during the dry season has declined over 40 years, and Arrau turtle (Podocnemis expansa) populations may be declining in part due to the reduction of this habitat as the length of the dry season continues to shorten [77]. Likewise, little has been published linking climatic conditions with survivorship in chelonians. Agassiz's desert tortoises (Gopherus agassizii) in California experienced a persistent drought from 1997 to 2002 and survivorship declined during this period, perhaps due to an increase in the coyote (Canis latrans) predation rate [78]. Likewise, a decrease in winter rainfall resulted in reduced survivorship for juvenile and immature Hermann's tortoises (Testudo hermanni) in Spain [79].

\subsection{Communities}

Community-level changes due to anthropogenic climate change could include changes in community composition, the potential for non-reproducing invasive species to begin reproducing, changes in the prey base, and changes in interactions. While there are several studies documenting community-level changes in some taxa (e.g., [80]), very few studies have been published documenting existing community changes involving chelonians that were linked to temperature.

One notable study that documented community-level changes occurred in Australia. A substantial change in turtle communities in the Murray River and its floodplain occurred between sampling in 1976-1982 and sampling in 2009-2011, with a 91\% decline in catch per unit effort (CPUE) for the eastern snake-necked turtle (Chelodina longicollis) and a 69\% reduction in CPUE for the Murray turtle (Emydura macquarii), but with no change in the CPUE for broad-shelled turtles (Chelodina expansa). This decline was attributed to a drought-induced loss of habitat, as well as predation pressure [23].

There have been several studies that have examined the potential impacts of introduced red-eared sliders on species and communities where they have been released. The observed impacts include competing with native species for basking sites, as well as feeding on a prey base that could potentially be affected if the population increases [81]. In France, red-eared sliders outcompete native turtle species for basking sites [82]. In South Africa, it is believed that red-eared sliders displaced African helmeted turtles (Pelomedusa subrufa) through competition [81]. Spanish terrapins (Mauremys leprosa) avoid waters where the chemical cue of the red-eared slider is present, which may explain the apparent displacement of this species by red-eared sliders [83]. It was also suggested that introduced red-eared sliders may feed on native Gambusia spp. and snails in Bermuda [84]. Finally, red-eared sliders may transmit parasites to native chelonians $[85,86]$.

\section{Predicted Effects}

When predicting the effects of climate change on chelonians, forecasted changes in distribution, phenology, and sex ratios are typically based upon Intergovernmental Panel on Climate Change (IPCC) predictions about climatic changes. The IPCC uses four different scenarios in order to forecast 
possible climatic changes [87]. The scenarios are based on the relative concentration pathways (RCPs), which simulate potential radiative forcing values for 2100 relative to 1750 . The relative concentration pathway 2.6 is characterized by greenhouse gas emissions peaking prior to 2020 and declining thereafter, resulting in radiative forcing of $+2.6 \mathrm{~W} / \mathrm{m}^{2}$ by 2100 [88]. Given existing trends in carbon dioxide during this decade, the RCP 2.6 scenario is no longer considered likely [89]. Relative concentration pathway 4.5 (where emissions peak around 2040 and then decline), RCP 6.0 (where emissions peak around 2080 and then decline), and RCP 8.5 (where emissions increase throughout the 21st century) result in radiative warming of $+4.5 \mathrm{~W} / \mathrm{m}^{2},+6.0 \mathrm{~W} / \mathrm{m}^{2}$, and $8.5 \mathrm{~W} / \mathrm{m}^{2}$, respectively [87]. Excluding the RCP 2.6 scenario, all scenarios resulted in an average global increase in excess of $1.5^{\circ} \mathrm{C}$ by the end of the twenty-first century, with two of the three scenarios predicting that the temperature is likely to exceed $2.0^{\circ} \mathrm{C}$ [87]. The potential impacts of these climatic changes are outlined below.

\subsection{Individuals}

Much remains to be determined in regard to how anthropogenic climate change could potentially affect individuals. Climate change could conceivably influence juvenile growth rate and age at maturity, with warmer temperatures leading to more rapid juvenile growth and a more rapid onset of sexual maturity [90]. Conversely, warmer temperatures may result in slower growth rates for some species [46]. Further research on this topic is called for as forecast changes in temperature and precipitation could potentially negatively impact these rates [43].

Populations of organisms at the edge of their range may play key roles in facilitating the maintenance or expansion of those species under anthropogenic climate change [91], although it is worth noting that genetic diversity at the edge of the range may be reduced relative to the core [92]. Refsnider and Janzen [93] suggested that the most likely outcome of anthropogenic warming is a combination of microevolution of thermal sensitivity coupled with plasticity in nesting behavior in chelonians. However, whether rapid evolutionary rescue will occur is uncertain, as there are few cases of it occurring in the wild [94]. Indeed, the current pace of warming will require the niche evolution for most organisms to evolve more than 10,000 times faster than typical rates [95].

\subsection{Populations}

The majority of the published literature dealing with the potential effects of climate change on turtles focused on population-level effects. Foden et al. [96] and Carr et al. [97] suggested that climate change vulnerability hinged on the sensitivity, adaptability, and exposure of the species considered. Species with high sensitivity and low adaptability are considered to be biologically sensitive to environmental change [98], while species with high exposure are considered to be "environmentally sensitive". Nine of the 46 chelonian species (19.6\%) studied by Böhm et al. [98] were considered to be highly vulnerable to climate change, and climate vulnerability for all reptilian species considered was highest in portions of the Amazon basin and northwestern South America, southwestern USA, and parts of southeastern Asia. For example, changes in the hydrology of the Amazon basin, leading to shorter dry periods, could be detrimental to the reproductive success of the Arrau turtle (Podocnemis expansa), as this species nests along alluvial riverbanks [77].

The range of most turtle species is affected by temperature [99], with precipitation also being important for freshwater species [100]; consequently, it is expected that climate change should have a pronounced effect on turtles. In general, warmer temperatures should relax thermal barriers at the poleward edge of the range [101]. However, the interaction between temperature and precipitation can limit distributional changes if there is insufficient water availability for organisms to take advantage of warmer conditions [102]. Both range extensions and range contractions can be viewed as a series of stages, with range extensions including arrival, increase in populations, and persistence, and range contractions consisting of a decline in performance, decline in population, and local extinction [103]. Dispersal is typically not included when creating species models, and when it has been explicitly 
included, climatic factors appear to be more important for describing species distributions than dispersal [104].

Many studies have noted that widespread declines in suitable habitat are expected to occur due to climate change. In Wisconsin, suitable habitat for Blanding's turtles is expected to shift northward by the 2050s and is anticipated to almost entirely disappear under the highest emission scenario [105]. In Sicily, suitable habitat for the Sicilian pond turtle (Emys trinacris) is expected to be greatly reduced under all scenarios examined [106]. Ihlow et al. [99] modeled the distributions of $78 \%$ of extant species and found the ranges of $86 \%$ of the species were predicted to contract. Alarmingly, suitable bioclimatic conditions for $12 \%$ of the species considered were forecast to be situated completely outside of the current distribution [99]. However, because chelonians are long-lived species, adults may persist in suboptimal habitats for years or decades, even with little or no annual recruitment [107]. Consequently, turtles and tortoises could conceivably persist in areas where climatic conditions are no longer suitable for reproduction.

Other studies have found more mixed effects. For example, the amount of suitable habitat for the Rio Grande Cooter (Pseudemys gorzugi) was predicted to increase by the 2050s and then decline substantially by the 2070s [108]. Similarly, models of the projected distribution of five Kinosternon species under various climate scenarios show that the distribution of two species were predicted to substantially decline, one was forecast to remain essentially unchanged, and the ranges for two species were expected to substantially increase [109]. The amount of suitable bioclimatic conditions for red-eared sliders in the Great Lakes Basin is expected to increase from $26 \%$ up to potentially $50 \%$ by 2050 [110].

Sea turtles are more vagile than freshwater or terrestrial turtles and therefore may be more suited to take advantage of rapidly warming climatic conditions. Witt et al. [111] suggested that the oceanic range of loggerhead turtles may expand in the Mediterranean Sea and Atlantic Ocean, while Pike $[53,112]$ suggested that nesting locations for Kemp's ridley and flatback turtles are likely to expand poleward. Likewise, leatherback turtles are expected to continue expanding their range into higher latitudes [54]. However, as turtle species expand their range in response to climate change, they could conceivably expand into areas that reduce hatching success due to anthropogenic disturbance and competition with other species [53]. In addition, exposure to new predators and parasites could potentially have deleterious effects on hatching success and survivorship [113,114].

Warmer temperatures may also facilitate the spread of non-native chelonians. Lever [115] described 18 chelonian species that have been introduced into new countries. Five species, including red-eared slider, European pond turtle (Emys orbicularis), angulate tortoise (Chersina angulata), eastern spur-thighed tortoise (Testudo graeca), and Herman's tortoise, have been introduced into areas substantially cooler than their native range. It is possible that a warming climate may facilitate reproduction and survivorship in these areas in the future. For example, red-eared sliders (Trachemys scripta) have been introduced to more than 30 countries across the globe [115]. In Italy, the most important variable explaining the presence of reproducing versus non-reproducing populations of this species were summer temperatures, with warmer summer temperatures linked to reproducing populations [21]. Due to climate change, areas expected to become suitable for this species are expected to increase [21]. In Europe, successful reproduction by red-eared sliders was initially reported to occur only in southern areas with Mediterranean climates, but locally-hatched offspring have now been documented in Serbia, Austria, Switzerland, Slovenia, and the Czech Republic [116].

There are very few studies on how climate change might affect survivorship in chelonians. Because growth rates are related to temperature and precipitation, climate change can potentially result in reduced growth rates leading to reduced survivorship [43]. Elevated incubation temperatures can lead to developmental abnormalities or reduced embryo viability in turtles [117-119]. Excessively warm temperatures can also result in smaller hatchlings with impaired neuromuscular coordination and reduced locomotor performance [120,121]. Elevated nest temperatures can also lead to increased feminization and, at extremely high temperatures, may result in lower levels of hatchling production [122]. However, at least one species, the flatback sea turtle, appears to be able to tolerate 
incubation temperatures of more than $5{ }^{\circ} \mathrm{C}$ relative to the control without experiencing an increase in developmental abnormalities or mortality [123].

The nesting success of Hawksbill turtles in Brazil is expected to decline up to $11 \%$ by 2100 due to warmer and wetter conditions [124]. The number of leatherback turtles nesting on the northwest portion of Costa Rica is expected to decline by $7 \%$ per decade during the 21st century [125]. Changes in ocean conditions were expected to have only a small impact; instead, the primary driver of the decline was a projected $2.5^{\circ} \mathrm{C}$ increase in the temperature of the nesting beach resulting in lower hatching success and reduced hatchling emergence rates [125]. Spatiotemporal variation in warming patterns means that there is a high risk of conditions becoming excessively warm in southeast Asia, a slight risk in the western Atlantic, and a low risk in the eastern Atlantic [126].

From 1993 through to the end of 2015, the global mean sea level rose by approximately three $\mathrm{mm}$ per year, resulting in an increase of approximately $49 \mathrm{~mm}$ during this time period [127]. During the 21st century, sea level is projected to rise globally by $17 \mathrm{~cm}$ to $82 \mathrm{~cm}$ [87]. This predicted sea level rise will reduce the amount of suitable beach for nesting sea turtles, with one author suggesting that a $0.5 \mathrm{~m}$ increase may result in the loss of $32 \%$ of total beach area [128]. The sea level rise is also expected to negatively impact diamondback terrapins (Malaclemys terrapin) in Chesapeake Bay by inundating existing nesting sites and reducing the amount of habitat available for foraging [129]. Sea level rise is also predicted to lead to higher spring tides, which could potentially result in flooded nests, with some waterlogged nests exhibiting up to $100 \%$ mortality rates [130], although some eggs may still hatch after occasional tidal inundation [131].

An increase in the incidence and severity of extreme weather events is anticipated as a result of anthropogenic climate change (IPCC 2014). In particular, droughts will become more common in drylands, despite a projected increase in precipitation in some areas, as vegetation changes lead to increased interception of water by vegetation and litter [132]. Droughts have been linked with declines in survivorship, habitat losses, and changes in predation pressure $[23,78,133]$. In southeastern Asia, for example, conditions are expected to become drier in most countries, excluding the Philippines, which may lead to habitat loss for freshwater turtles [134]. However, there have been very few studies that investigated this, and further research is called for to investigate the effects of increasing drought frequency and severity on chelonians [61]. In other areas, extreme flooding events may increase in duration and frequency [87], but little is known about how this may affect turtles. Extreme flooding events in a riverine habitat apparently do not affect survival, recruitment, or population growth rates in painted turtles [135]. However, reduced survivorship of the Chocoan river turtle (Rhinoclemmys nasuta) in Colombia is associated with extreme flooding events that may change the habitat characteristics and hydrology of streams [136].

It is generally accepted that increasing temperatures will skew sex ratios of turtles with TSD $[137,138]$ with potentially catastrophic effects, particularly on the equatorial side of the range $[119,139]$. However, there is disagreement over the severity of the consequences of this skew and whether chelonians will exhibit sufficient plasticity to cope. TSD could potentially be adaptive in the face of climate change, as warmer temperatures should lead to more balanced sex ratios at the edge of species' distributional limits that are currently restricted by cold temperatures (e.g., at the northern edge of the range in the northern hemisphere [140]). It was proposed that some nesting grounds of green sea turtles near the Great Barrier reef will still produce male offspring even under the RCP 8.5 scenario [141]. There is also some evidence that male sea turtle mating patterns may buffer against feminization in a warming world, as male green turtles move between multiple rookeries and may have a shorter reproductive interval than females [142]. Nonetheless, there is broad agreement that increasing feminization is likely in this area [143]. While it appears likely that increasing feminization will occur in some areas and some species, it is unclear what the population-level effects of this developing sex ratio bias may be as species distributions shift.

It is possible that behavioral plasticity might mitigate the effects of climate change for some species [66]. Theoretically, turtles could exhibit plasticity with respect to nest-building behavior and phenology, and 
there is some evidence that chelonians exhibit such plasticity [144]. Some authors suggested that changes in phenology may offset predicted change in sex ratios [63] and there are suggestions that there is considerable phenotypic plasticity in nesting phenology [93]. However, others suggest that female chelonians may not be able to sufficiently advance the nesting date to avoid skewed sex ratios [119]. For example, although female turtles can adjust the depth of their nest, the cues that female painted turtles use to adjust nest depth do not necessarily predict future incubation conditions, therefore, it is unlikely that this species will be able to compensate for skewed TSD due to climate change [145].

Relatively little work has been conducted to predict the effects of climate change on chelonian phenology. The relationship between the date of first nesting for loggerhead turtles and temperature exhibits a steeper gradient at higher latitudes, suggesting that phenological changes will be more pronounced at the poleward edges of a species range [146]. Warming soil temperatures could also conceivably affect emergence time, particularly of hatchlings that overwinter in the nest [61]. Warmer substrate temperatures may also improve incubation success for green turtles [147], although this suggestion is contested, with some authors arguing that green turtles will need to spatiotemporally adjust reproductive strategies [148].

\subsection{Communities}

The climate of the globe is changing, but it is not changing at a constant pace. Some areas are warming faster than others and air temperatures are rising faster than the temperature of the top ocean layer [87]. The median pace of warming since 1960 has been $0.24{ }^{\circ} \mathrm{C}$ per decade on land but only $0.07^{\circ} \mathrm{C}$ per decade in the oceans [149]. Although distributional shifts are expected to proceed more rapidly on land than in the oceans, phenological shifts are anticipated to occur more rapidly in marine environments than in terrestrial ones due to more limited seasonal variation in temperatures [149]. Generally, species appear to be shifting poleward at approximately $17 \mathrm{~km}$ per decade, although there is considerable variation due to variation in the internal and external drivers that determine the distribution of a species [150]. Given the limited vagility of turtles, it seems likely that they will not be able to shift their range as rapidly as many other organisms [10]. However, not all species appear to be shifting their range in response to climate change. Mangroves, for example, show no evidence of expanding their range [151], possibly because of extremes in environmental variability [152]. After the last ice age, vegetation appears to have responded relatively slowly [153] and plant communities may not be able to fully keep pace with environmental changes [154]. Forest inventory data in eastern North America suggests that tree species ranges are shifting poleward at only $50 \%$ of the spatial velocity of existing climate change [155]. The observed variation in rates of the distributional shift of vegetation in response to climate change may lead to a disequilibrium in communities and potential turtle habitat in the coming decades and centuries. It will be necessary to assess future habitat suitability for effective conservation planning and management [156], but this assessment will need to take into account the potential lag between changing climatic conditions and vegetative communities.

Relatively few studies specifically investigated how community level changes due to anthropogenic climate change could affect chelonians. However, in Australia, high faunal turnover is expected in freshwater systems, with up to six turtle species disappearing from some areas [157]. Turtle species richness is expected to decline in the northern part of Murray-Darling Basin, Gulf of Carpentaria, and Northeast Coast drainage divisions, while turtle species richness is predicted to increase in the southeastern part of Murray-Darling Basin and the Northern Territory [157].

Shifts in community composition will probably be most noticeable at the cold-edge portion of the range as species expand their range poleward, and at the warm-edge portions of the range as individuals disappear due to increasingly unfavorable climatic conditions and biotic interactions. Although there is some evidence that warm-edge limits are due to biotic factors such as competition [101], the majority of studies found that abiotic factors were more important [158]. For example, in the eastern US, the distribution of Emydinae and Deirochelyinae does not appear to be due to competitive exclusion, but rather appears to be due to historical biogeography, which in turn is due to niche conservatism [159]. 
For some species, the critical thermal maximum (CTM), the temperature at which the organism loses the ability to escape from conditions that will lead to mortality [160], may determine the southern boundary of a range [159], and turtles stressed by drought may have lower CTMs [133]. Consequently, changes in communities at the southern edge of the range may be driven not just by gradually warming temperatures, but also by an increase in heat waves and an increase in drought frequency and severity.

\section{Research Priorities and Knowledge Gaps}

Although species distribution models are useful in examining general distributional patterns, they tend to over- or underestimate the distribution of the organism in question. For example, an expert panel found that models describing the distribution of seventeen vertebrates of interest might be inaccurate due to difficulty in identifying rain shadows, inability to identify microrefugia (but see [161]), insufficient data on upper temperature tolerance for many species, geographical barriers to dispersal, competitor species, disease, and difficulty in modeling distributions for species with very small ranges or with sparse locality data [162]. In addition, the choice of bioclimatic variables used as predictors can also influence model projections [163]. Consequently, the continued refinement of ecological niche models will be necessary in order to more accurately describe potential distributions of species. Additionally, an experimental approach to identify the proximate and ultimate mechanisms that define a species range would greatly aid in our understanding of current distributional patterns and how they may change under anthropogenic climate change.

As noted previously, there are relatively few studies on the effects of anthropogenic climate change on individuals. One promising avenue of investigation is to use biologging to examine individual responses to climate change, particularly with respect to thermal biology, phenology, and microhabitat selection [164]. For example, temperature and light loggers can be used to determine seasonal and annual patterns in activity, including hibernation onset, and termination [165]. Biologgers can also be used to explore thermal ecology and may be able to quantify physiological flexibility, as well as aid in documenting genetic variation in thermal tolerance [166]. Data loggers in combination with video cameras were used in turtles to explore feeding and behavioral interactions (e.g., [167-170]), as well as thermoregulatory performance and habitat selection (e.g., [171]). Biologging chelonians can thus provide information on physiological and behavioral responses to environmental conditions, as well as investigating behavioral plasticity in response to environmental changes [172].

Fisher's principle states that a 1:1 sex ratio should be an evolutionarily stable strategy [173]. Much of the existing research on the potential effects of climate change on chelonians has focused on how warming temperatures may skew sex ratios due to TSD, leading to increased feminization that could have catastrophic effects on populations $[119,139]$. Progress is being made on determining the mechanism by which TSD occurs and how to accurately quantify it [174]. However, turtle sex ratios can be biased yet still persist on the landscape (e.g., [175,176]), and an increase in the proportion of females may, at least temporarily, lead to population growth [177]. However, protracted rainfall can result in lowered nest temperatures [178]; there is still a great deal of uncertainty in how rainfall will change over tropical areas in the coming decades [179]. In addition, differing survivorship rates between the sexes may potentially counter-balance some of the effects of TSD. For example, road mortality may disproportionately affect female turtles, leading to an increase in the proportion of males in the population [180].

Another avenue of research that should be explored is the effect of climate change on body size. Bergman's rule hypothesizes that the body size of large homeotherms should be negatively related to environmental temperature, with larger body sizes present in colder climes [181]. Although initially applied to endotherms, Bergmann's Rule has been widely studied in poikilotherms as well [182]. Several studies noted a link between body size in chelonians and latitude/temperature (e.g., [183-185]). However, Bergmann's Rule does not apparently apply to all species or sexes [186], and many species are exhibiting shrinking body sizes in response to climate change [187]. Although incubation temperatures can affect hatchling size and growth $[46,188,189]$, studies examining the effect of warmer temperatures on ultimate body size are lacking. One interesting avenue of research might be to investigate whether 
warming temperatures are leading to different ultimate body sizes in turtles, as body size can influence fecundity and survivorship [190-192].

Another interesting avenue of research might be to explore whether the spatial and temporal incidences of cold-stunned sea turtles are changing, particularly in the northeastern US. Kemp's ridley turtles, for example, which are frequently picked up along beaches in the northeastern US after a sudden cold weather event in autumn causes water temperatures to drop precipitously [193]. Somewhat counterintuitively, although ocean temperatures in this region have been warming, cold-stun strandings have increased substantially since the 1970s [194]. Reducing adult mortality from by-catch or harvesting, alongside protecting nests of sea-faring chelonians, is widely regarded as the most important conservation action that can be taken to protect sea turtles [195-197]. However, the projected increase in cold-stun strandings in the northeastern US could potentially affect survivorship of this critically endangered species and thus is also of conservation concern.

As species expand their range, the population density at the poleward edge is likely to be low, thus leading to relatively low detectability. Environmental DNA may offer a way to determine the presence of freshwater chelonian species in novel locations. Recent environmental DNA (eDNA) techniques were developed to survey for aquatic species and offer the potential to easily and efficiently survey for the presence of species of interest. Environmental DNA is genetic material obtained directly from an environmental sample such as soil, sediment, or water, without any obvious biological source material [198]. Ficetola et al. [199] demonstrated that it was possible to detected aquatic vertebrates using environmental DNA from water samples, thus offering the potential to improve detection efficiency and reduce detection cost. This approach was used on a variety of organisms, including salamanders [200], fish [201], and frogs [202], that permanently reside in the water. This technique was also recently adapted for use in freshwater turtles [203] and it may provide a more cost-effective and efficient method to determine whether introduced species are present [204].

Finally, assessments of resilience and development of methods to mitigate the impacts should be investigated. Phenotypic plasticity and genetic variation could potentially buffer against some of the predicted deleterious effects of climate change, but there is a great deal of uncertainty about how effective this will be [205]. Much of the existing work on this was carried out on marine turtles. For example, the resilience of 58 marine turtle regional management units was investigated [206]. However, no comparable study has been conducted for the vast majority of non-marine chelonians. Despite this, some of the techniques proposed to help mitigate the effects of climate change on marine turtles could be applied to other species as well. The construction of sea walls, for example, could help protect some beaches [207]. Increasing the number of males in a population with TSD can be as simple as creating a simple artificial screen in order to reduce nest temperatures [208]. The use of palm leaves for shade, for example, was successful in reducing temperatures by $0.6{ }^{\circ} \mathrm{C}$ at a sea turtle rookery in St Eustatius, in the northeastern Caribbean [209]. Watering nests was also suggested as a method to reduce nest temperatures, although the effects are believed to be most beneficial in dry areas with low rainfall [210]. Assisted migration and genetic supplementation were also suggested as possible solutions, but as yet there appear to be no published studies on this topic among chelonians [211]. Likewise, guidelines on when to engage in management intervention are still being discussed [212,213].

\section{Conclusions}

Anthropogenic climate change will have a pronounced effect on the individual, population, and community ecology of turtles. Although chelonians have withstood previous climatic changes [211], the forecasted rate of change is considerably more rapid than any changes in at least the last 65 million years [214]. Consequently, organisms may not be able to adapt to climate change if the rate of change is too rapid and the demography is not sufficiently dynamic [215]. Since chelonians in general exhibit long generation times with generally high adult survivorship coupled with high juvenile mortality and limited vagility, they are ill-suited to respond rapidly to climate change. Although turtles possess a variety of behavioral and physiological mechanisms to cope with suboptimal conditions, 
the unparalleled rate of change is likely to result in local to widespread extirpation, although a few species may benefit. Further research on enhancing resilience and developing methods to mitigate the effects of climate change will be necessary to ensure that widespread losses do not occur.

Funding: This research received no external funding.

Acknowledgments: I thank M. Saleh, J. Lucas, P. Stone, and two anonymous reviewers for their comments on drafts of this manuscript.

Conflicts of Interest: The author declares no conflict of interest.

\section{References}

1. Butler, C.J. The disproportionate effect of global warming on the arrival dates of short-distance migratory birds in North America. Ibis 2003, 145, 484-495. [CrossRef]

2. Cotton, P.A. Avian migration phenology and global climate change. Proc. Natl. Acad. Sci. USA 2003, 100, 12219-12222. [CrossRef] [PubMed]

3. Hughes, L. Biological consequences of global warming: Is the signal already apparent? Trends Ecol. Evol. 2000, 15, 56-61. [CrossRef]

4. Hurlbert, A.H.; Liang, Z. Spatiotemporal Variation in Avian Migration Phenology: Citizen Science Reveals Effects of Climate Change. PLoS ONE 2012, 7, e31662. [CrossRef] [PubMed]

5. Lafferty, K.D. The ecology of climate change and infectious diseases. Ecology 2009, 90, 888-900. [CrossRef] [PubMed]

6. Parmesan, C.; Yohe, G. A globally coherent fingerprint of climate change impacts across natural systems. Nature 2003, 421, 37-42. [CrossRef] [PubMed]

7. Perry, A.L.; Low, P.J.; Ellis, J.R.; Reynolds, J.D. Climate Change and Distribution Shifts in Marine Fishes. Science 2005, 308, 1912-1915. [CrossRef] [PubMed]

8. Sekercioglu, C.H.; Schneider, S.H.; Fay, J.P.; Loarie, S.R. Climate change, elevational range shifts, and bird extinctions. Conserv. Biol. 2008, 22, 140-150. [CrossRef]

9. Thuiller, W.; Broennimann, O.; Hughes, G.; Alkemade, J.R.M.; Midgley, G.F.; Corsi, F. Vulnerability of African mammals to anthropogenic climate change under conservative land transformation assumptions. Glob. Chang. Biol. 2006, 12, 424-440. [CrossRef]

10. Gibbon, J.W.; Scott, D.E.; Ryan, T.J.; Buhlmann, K.A.; Tuberville, T.D.; Metts, B.S.; Greene, J.L.; Mills, T.; Leiden, Y.; Poppy, S.; et al. The Global Decline of Reptiles, Déjà Vu Amphibians. BioScience 2000, 50, 653-666. [CrossRef]

11. Loarie, S.R.; Duffy, P.B.; Hamilton, H.; Asner, G.P.; Field, C.B.; Ackerly, D.D. The velocity of climate change. Nature 2009, 462, 1052. [CrossRef] [PubMed]

12. IUCN. The IUCN Red List of Threatened Species. Version 2019-1. 2019. Available online: http://www. iucnredlist.org (accessed on 17 April 2019).

13. Browne, C.L.; Hecnar, S.J. Species loss and shifting population structure of freshwater turtles despite habitat protection. Biol. Conserv. 2007, 138, 421-429. [CrossRef]

14. Berggren, Å.; Björkman, C.; Bylund, H.; Ayres, M.P. The distribution and abundance of animal populations in a climate of uncertainty. Oikos 2009, 118, 1121-1126. [CrossRef]

15. Janzen, F.J. Climate change and temperature-dependent sex determination in reptiles. Proc. Natl. Acad. Sci. USA 1994, 91, 7487-7490. [CrossRef] [PubMed]

16. Humphries, M.M.; Thomas, D.W.; Speakman, J.R. Climate-mediated energetic constraints on the distribution of hibernating mammals. Nature 2002, 418, 313-316. [CrossRef] [PubMed]

17. Hughes, T.P.; Baird, A.H.; Bellwood, D.R.; Card, M.; Connolly, S.R.; Folke, C.; Grosberg, R.; Hoegh-Guldberg, O.; Jackson, J.B.C.; Kleypas, J.; et al. Climate Change, Human Impacts, and the Resilience of Coral Reefs. Science 2003, 301, 929-933. [CrossRef] [PubMed]

18. Shinn, E.A.; Smith, G.W.; Prospero, J.M.; Betzer, P.; Hayes, M.L.; Garrison, V.; Barber, R.T. African dust and the demise of Caribbean Coral Reefs. Geophys. Res. Lett. 2000, 27, 3029-3032. [CrossRef]

19. Weisrock, D.W.; Janzen, F.J. Thermal and fitness-related consequences of nest location in Painted Turtles (Chrysemys picta). Funct. Ecol. 1999, 13, 94-101. [CrossRef] 
20. Du, W.-G.; Ji, X. The effects of incubation thermal environments on size, locomotor performance and early growth of hatchling soft-shelled turtles, Pelodiscus sinensis. J. Therm. Biol. 2003, 28, 279-286. [CrossRef]

21. Ficetola, G.F.; Thuiller, W.; Padoa-Schioppa, E. From introduction to the establishment of alien species: Bioclimatic differences between presence and reproduction localities in the slider turtle. Divers. Distrib. 2009, 15, 108-116. [CrossRef]

22. Lovich, J.; Agha, M.; Meulblok, M.; Meyer, K.; Ennen, J.; Loughran, C.; Madrak, S.; Bjurlin, C. Climatic variation affects clutch phenology in Agassiz's desert tortoise Gopherus agassizii. Endanger. Species Res. 2012, 19, 63-74. [CrossRef]

23. Chessman, B.C. Declines of freshwater turtles associated with climatic drying in Australia's Murray-Darling Basin. Wildl. Res. 2011, 38, 664-671. [CrossRef]

24. Christiansen, J.L.; Bernstein, N.P.; Phillips, C.A.; Briggler, J.T.; Kangas, D. Declining populations of Yellow Mud Turtles (Kinosternon flavescens) in Iowa, Illinois, and Missouri. Southwest. Nat. 2012, 57, 304-314. [CrossRef]

25. Poloczanska, E.S.; Limpus, C.J.; Hays, G.C. Chapter 2 Vulnerability of Marine Turtles to Climate Change. Adv. Mar. Biol. 2009, 56, 151-211. [PubMed]

26. Hawkes, L.A.; Broderick, A.C.; Godfrey, M.H.; Godley, B.J. Climate change and marine turtles. Endanger. Species Res. 2009, 7, 137-154. [CrossRef]

27. Allen, T.F.H.; Hoekstra, T.W. The confusion between scale-defined levels and conventional levels of organization in ecology. J. Veg. Sci. 1990, 1, 5-12. [CrossRef]

28. Lidicker, W.Z., Jr. Levels of organization in biology: On the nature and nomenclature of ecology's fourth level. Biol. Rev. 2008, 83, 71-78. [CrossRef]

29. Visser, M.E. Keeping up with a warming world; assessing the rate of adaptation to climate change. Proc. R. Soc. B Biol. Sci. 2008, 275, 649-659. [CrossRef] [PubMed]

30. Thomson, J.A.; Burkholder, D.A.; Heithaus, M.R.; Fourqurean, J.W.; Fraser, M.W.; Statton, J.; Kendrick, G.A. Extreme temperatures, foundation species, and abrupt ecosystem change: An example from an iconic seagrass ecosystem. Glob. Chang. Biol. 2015, 21, 1463-1474. [CrossRef]

31. Hochscheid, S.; Bentivegna, F.; Hays, G.C. First records of dive durations for a hibernating sea turtle. Biol. Lett. 2005, 1, 82-86. [CrossRef] [PubMed]

32. Plotkin, P.T.; Spotila, J.R. Post-nesting migrations of loggerhead turtles Caretta caretta from Georgia, USA: Conservation implications for a genetically distinct subpopulation. Oryx 2002, 36, 396-399. [CrossRef]

33. Shoop, C.R.; Kenney, R.D. Seasonal Distributions and Abundances of Loggerhead and Leatherback Sea Turtles in Waters of the Northeastern United States. Herpetol. Monogr. 1992, 6, 43-67. [CrossRef]

34. Milton, S.; Lutz, P. Physiological and Genetic Responses to Environmental Stress. In The Biology of Sea Turtles; Lutz, P., Musick, J.A., Wyneken, J., Eds.; CRC Press: Boca Raton, FL, USA, 2003; Volume II, pp. 163-198.

35. Refsnider, J.M.; Palacios, M.G.; Reding, D.M.; Bronikowski, A.M. Effects of a novel climate on stress response and immune function in painted turtles (Chrysemys picta). J. Exp. ZooL. Part A: Ecol. Genet. Physiol. 2015, 323, 160-168. [CrossRef]

36. Kolbe, J.J.; Janzen, F.J. Impact of nest-site selection on nest success and nest temperature in natural and disturbed habitats. Ecology 2002, 83, 269-281. [CrossRef]

37. Santidrián Tomillo, P.; Fonseca, L.; Paladino, F.V.; Spotila, J.R.; Oro, D. Are thermal barriers "higher” in deep sea turtle nests? PLOS ONE 2017, 12, e0177256. [CrossRef]

38. Wilson, D.S. Nest-Site Selection: Microhabitat Variation and Its Effects on the Survival of Turtle Embryos. Ecology 1998, 79, 1884-1892. [CrossRef]

39. Zhao, B.; Li, T.; Shine, R.; Du, W.G. Turtle embryos move to optimal thermal environments within the egg. Biol. Lett. 2013, 9, 20130337. [CrossRef]

40. Du, W.G.; Zhao, B.; Chen, Y.; Shine, R. Behavioral thermoregulation by turtle embryos. Proc. Natl. Acad. Sci. USA 2011, 108, 9513-9515. [CrossRef] [PubMed]

41. Telemeco, R.S.; Gangloff, E.J.; Cordero, G.A.; Mitchell, T.S.; Bodensteiner, B.L.; Holden, K.G.; Mitchell, S.M.; Polich, R.L.; Janzen, F.J. Reptile Embryos Lack the Opportunity to Thermoregulate by Moving within the Egg. Am. Nat. 2016, 188, E13-E27. [CrossRef]

42. Cordero, G.A.; Telemeco, R.S.; Gangloff, E.J. Reptile embryos are not capable of behavioral thermoregulation in the egg. Evol. Dev. 2018, 20, 40-47. [CrossRef] [PubMed] 
43. McCallum, M.; McCallum, J.; Trauth, S. Predicted climate change may spark box turtle declines. Aphibia-Reptilia 2009, 30, 259-264. [CrossRef]

44. Marn, N.; Jusup, M.; Legović, T.; Kooijman, S.A.L.M.; Klanjšček, T. Environmental effects on growth, reproduction, and life-history traits of loggerhead turtles. Ecol. Model. 2017, 360, 163-178. [CrossRef]

45. Layfield, J.A.; Nancekivell, E.G.; Brooks, R.J.; Bobyn, M.L.; Galbraith, D.A. Maternal and environmental influences on growth and survival of embryonic and hatchling snapping turtles (Chelydra serpentina). Can. J. Zool. 1991, 69, 2667-2676.

46. O'Steen, S. Embryonic temperature influences juvenile temperature choice and growth rate in snapping turtles Chelydra serpentina. J. Exp. Biol. 1998, 201, 439-449. [PubMed]

47. Willette, D.A.; Tucker, J.K.; Janzen, F.J. Linking climate and physiology at the population level for a key life-history stage of turtles. Can. J. Zool. 2005, 83, 845-850. [CrossRef]

48. Gibbons, J.W.; Nelson, D.H. The evolutionary significance of delayed emergence from the nest by hatchling turtles. Evolution 1978, 32, 297-303. [CrossRef]

49. Costanzo, J.P.; Dinkelacker, S.A.; Iverson, J.B.; Lee, J.R.E. Physiological Ecology of Overwintering in the Hatchling Painted Turtle: Multiple-Scale Variation in Response to Environmental Stress. Physiol. Biochem. Zool. 2004, 77, 74-99. [CrossRef]

50. Reece, J.S.; Passeri, D.; Ehrhart, L.; Hagen, S.C.; Hays, A.; Long, C.; Noss, R.F.; Bilskie, M.; Sanchez, C.; Schwoerer, M.V.; et al. Sea level rise, land use, and climate change influence the distribution of loggerhead turtle nests at the largest USA rookery (Melbourne Beach, Florida). Mar. Ecol. Prog. Ser. 2013, 493, 259-274. [CrossRef]

51. Franch, M.; Montori, A.; Sillero, N.; Llorente, G.A. Temporal analysis of Mauremys leprosa (Testudines, Geoemydidae) distribution in northeastern Iberia: Unusual increase in the distribution of a native species. Hydrobiologia 2015, 757, 129-142. [CrossRef]

52. Johnson, S.A.; Bass, A.L.; Libert, B.; Marshall, M.; Fulk, D. Kemp's Ridley (Lepidochelys kempi) nesting in Florida. Fla. Sci. 1999, 62, 194-204.

53. Pike, D.A. Forecasting range expansion into ecological traps: Climate-mediated shifts in sea turtle nesting beaches and human development. Glob. Chang. Biol. 2013, 19, 3082-3092. [CrossRef] [PubMed]

54. McMahon, C.R.; Hays, G.C. Thermal niche, large-scale movements and implications of climate change for a critically endangered marine vertebrate. Glob. Chang. Biol. 2006, 12, 1330-1338. [CrossRef]

55. Ewert, M.A.; Jackson, D.R.; Nelson, C.E. Patterns of temperature-dependent sex determination in turtles. J. Exp. Zool. 1994, 270, 3-15. [CrossRef]

56. Bull, J.J.; Legler, J.M.; Vogt, R.C. Non-Temperature Dependent Sex Determination in Two Suborders of Turtles. Copeia 1985, 1985, 784-786. [CrossRef]

57. Ewert, M.A.; Nelson, C.E. Sex Determination in Turtles: Diverse Patterns and Some Possible Adaptive Values. Copeia 1991, 1991, 50-59. [CrossRef]

58. Bull, J.J. Sex determination in reptiles. Q. Rev. Biol. 1980, 55, 3-21. [CrossRef]

59. Pieau, C.; Mrosovsky, N. Transitional range of temperature, pivotal temperatures and thermosensitive stages for sex determination in reptiles. Amphibia-Reptilia 1991, 12, 169-179. [CrossRef]

60. Ewert, M.A.; Lang, J.W.; Nelson, C.E. Geographic variation in the pattern of temperature-dependent sex determination in the American snapping turtle (Chelydra serpentina). J. Zool. 2005, 265, 81-95. [CrossRef]

61. Gibbons, J.W.; Lovich, J.E. Where has turtle ecology been, and where is it going? Herpetologica 2019, 75, 4-20. [CrossRef]

62. Jensen, M.P.; Allen, C.D.; Eguchi, T.; Bell, I.P.; Lacasella, E.L.; Hilton, W.A.; Hof, C.A.; Dutton, P.H. Environmental Warming and Feminization of One of the Largest Sea Turtle Populations in the World. Curr. Biol. 2018, 28, 154-159. [CrossRef]

63. Laloë, J.O.; Esteban, N.; Berkel, J.; Hays, G.C. Sand temperatures for nesting sea turtles in the Caribbean: Implications for hatchling sex ratios in the face of climate change. J. Exp. Mar. Biol. Ecol. 2016, 474, 92-99. [CrossRef]

64. Schwanz, L.E.; Spencer, R.-J.; Bowden, R.M.; Janzen, F.J. Climate and predation dominate juvenile and adult recruitment in a turtle with temperature-dependent sex determination. Ecology 2010, 91, 3016-3026. [CrossRef]

65. Tucker, J.K.; Dolan, C.R.; Lamer, J.T.; Dustman, E.A. Climatic Warming, Sex Ratios, and Red-Eared Sliders (Trachemys scripta elegans) in Illinois. Chelonian Conserv. Biol. 2008, 7, 60-69. [CrossRef] 
66. Reid, B.N.; Peery, M.Z. Land use patterns skew sex ratios, decrease genetic diversity and trump the effects of recent climate change in an endangered turtle. Divers. Distrib. 2014, 20, 1425-1437. [CrossRef]

67. Pilcher, N.J.; Perry, L.; Antonopoulou, M.; Abdel-Moati, M.A.; Al Abdessalaam, T.Z.; Albeldawi, M.; Al Ansi, M.; Al-Mohannadi, S.F.; Baldwin, R.; Chikhi, A.; et al. Short-term behavioural responses to thermal stress by hawksbill turtles in the Arabian region. J. Exp. Mar. Biol. Ecol. 2014, 457, 190-198. [CrossRef]

68. Mitchell, T.S.; Refnsider, J.M.; Sethuraman, A.; Warner, D.A.; Janzen, F.J. Experimental assessment of winter conditions on turtle nesting behaviour. Evol. Ecol. Res. 2017, 18, 271-280.

69. Janzen, F.J.; Hoekstra, L.A.; Brooks, R.J.; Carroll, D.M.; Gibbons, J.W.; Greene, J.L.; Iverson, J.B.; Litzgus, J.D.; Michael, E.D.; Parren, S.G.; et al. Altered spring phenology of North American freshwater turtles and the importance of representative populations. Ecol. Evol. 2018, 8, 5815-5827. [CrossRef]

70. Del Monte-Luna, P.; Guzmán-Hernández, V.; Cuevas, E.A.; Arreguín-Sánchez, F.; Lluch-Belda, D. Effect of North Atlantic climate variability on hawksbill turtles in the Southern Gulf of Mexico. J. Exp. Mar. Biol. Ecol. 2012, 412, 103-109. [CrossRef]

71. Chaloupka, M.; Kamezaki, N.; Limpus, C. Is climate change affecting the population dynamics of the endangered Pacific loggerhead sea turtle? J. Exp. Mar. Biol. Ecol. 2008, 356, 136-143. [CrossRef]

72. Mazaris, A.D.; Kallimanis, A.S.; Tzanopoulos, J.; Sgardelis, S.P.; Pantis, J.D. Sea surface temperature variations in core foraging grounds drive nesting trends and phenology of loggerhead turtles in the Mediterranean Sea. J. Exp. Mar. Biol. Ecol. 2009, 379, 23-27. [CrossRef]

73. Patel, S.H.; Morreale, S.J.; Saba, V.S.; Panagopoulou, A.; Margaritoulis, D.; Spotila, J.R. Climate Impacts on Sea Turtle Breeding Phenology in Greece and Associated Foraging Habitats in the Wider Mediterranean Region. PLoS ONE 2016, 11, e0157170. [CrossRef] [PubMed]

74. Neeman, N.; Robinson, N.J.; Paladino, F.V.; Spotila, J.R.; O'Connor, M.P. Phenology shifts in leatherback turtles (Dermochelys coriacea) due to changes in sea surface temperature. J. Exp. Mar. Biol. Ecol. 2015, 462, 113-120. [CrossRef]

75. Rollinson, N.; Farmer, R.G.; Brooks, R.J. Widespread reproductive variation in North American turtles: Temperature, egg size and optimality. Zoology 2012, 115, 160-169. [CrossRef] [PubMed]

76. Hedrick, A.R.; Klondaris, H.M.; Corichi, L.C.; Dreslik, M.J.; Iverson, J.B. The effects of climate on annual variation in reproductive output in Snapping Turtles (Chelydra serpentina). Can. J. Zool. 2017, 96, 221-228. [CrossRef]

77. Eisemberg, C.C.; Balestra, R.A.M.; Famelli, S.; Pereira, F.F.; Bernardes, V.C.D.; Vogt, R.C. Vulnerability of Giant South American Turtle (Podocnemis expansa) nesting habitat to climate-change-induced alterations to fluvial cycles. Trop. Conserv. Sci. 2016, 9, 1-12. [CrossRef]

78. Lovich, J.E.; Yackulic, C.B.; Freilich, J.; Agha, M.; Austin, M.; Meyer, K.P.; Arundel, T.R.; Hansen, J.; Vamstad, M.S.; Root, S.A. Climatic variation and tortoise survival: Has a desert species met its match? Biol. Conserv. 2014, 169, 214-224. [CrossRef]

79. Bertolero, A.; Amengual, A.; Oro, D.; Fernández-Chacón, A.; Tavecchia, G.; Homar, V. Spatial heterogeneity in the effects of climate change on the population dynamics of a Mediterranean tortoise. Glob. Chang. Biol. 2011, 17, 3075-3088.

80. Princé, K.; Zuckerberg, B. Climate change in our backyards: The reshuffling of North America's winter bird communities. Glob. Chang. Biol. 2015, 21, 572-585. [CrossRef]

81. Ramsay, N.F.; Ng, P.K.A.; O'Riordan, R.M.; Chou, L.M. The Red-Eared Slider (Trachemys Scripta Elegans) in Asia: A Review. In Biological Invaders in Inland Waters: Profiles, Distribution, and Threats; Springer Netherlands: Heidelberg, Germany, 2007; Volume 2, pp. 161-174.

82. Cadi, A.; Joly, P. Competition for basking places between the endangered European pond turtle (Emys orbicularis galloitalica) and the introduced red-eared slider (Trachemys scripta elegans). Can. J. Zool. 2003, 81, 1392-1398. [CrossRef]

83. Polo-Cavia, N.; López, P.; Martín, J. Interspecific differences in chemosensory responses of freshwater turtles: Consequences for competition between native and invasive species. Biol. Invasions 2009, 11, 431-440. [CrossRef]

84. Davenport, J.; Black, K.D.; Burnell, G.; Cross, T.; Culloty, S.; Ekaratne, S.; Furness, B.; Mulcahy, M.; Thetmeyer, H. Aquaculture: The Ecological Issues; Blackwell: Oxford, UK, 2003. 
85. Verneau, O.; Palacios, C.; Platt, T.; Alday, M.; Billard, E.; Allienne, J.-F.; Basso, C.; Du Preez, L.H. Invasive species threat: Parasite phylogenetics reveals patterns and processes of host-switching between non-native and native captive freshwater turtles. Parasitology 2011, 138, 1778-1792. [CrossRef] [PubMed]

86. Meyer, L.; Du Preez, L.; Bonneau, E.; Héritier, L.; Quintana, M.F.; Valdeón, A.; Sadaoui, A.; Kechemir-Issad, N.; Palacios, C.; Verneau, O. Parasite host-switching from the invasive American red-eared slider, Trachemys scripta elegans, to the native Mediterranean pond turtle, Mauremys leprosa, in natural environments. Aquat. Invasions. 2015, 10, 79-91. [CrossRef]

87. IPCC. Climate Change 2013, The Physical Science Basis; Stocker, T.F., Qin, D., Plattner, G.K., Tignor, M., Allen, S.K., Boschung, J., Nauels, A., Xia, Y., Bex, V., Midgley, P.M., Eds.; Cambridge University Press: Cambridge, UK, 2014.

88. Van Vuuren, D.P.; Edmonds, J.; Kainuma, M.; Riahi, K.; Thomson, A.; Hibbard, K.; Hurtt, G.C.; Kram, T.; Krey, V.; Lamarque, J.F.; et al. The representative concentration pathways: An overview. Clim. Chang. 2011, 109, 5. [CrossRef]

89. Sanford, T.; Frumhoff, P.C.; Luers, A.; Gulledge, J. The climate policy narrative for a dangerously warming world. Nat. Clim. Chang. 2014, 4, 164-166. [CrossRef]

90. Frazer, N.B.; Greene, J.L.; Gibbons, J.W. Temporal Variation in Growth Rate and Age at Maturity of Male Painted Turtles, Chrysemys picta. Am. Midl. Nat. 1993, 130, 314-324. [CrossRef]

91. Rehm, E.M.; Olivas, P.; Stroud, J.; Feeley, K.J. Losing your edge: Climate change and the conservation value of range-edge populations. Ecol. Evol. 2015, 5, 4315-4326. [CrossRef]

92. Cahill, A.E.; Levinton, J.S. Genetic differentiation and reduced genetic diversity at the northern range edge of two species with different dispersal modes. Mol. Ecol. 2016, 25, 515-526. [CrossRef]

93. Refsnider, J.M.; Janzen, F.J. Temperature-dependent sex determination under rapid anthropogenic environmental change: Evolution at a turtle's pace? J. Hered. 2016, 107, 61-70. [CrossRef]

94. Carlson, S.M.; Cunningham, C.J.; Westley, P.A. Evolutionary rescue in a changing world. Trends Ecol. Evol. 2014, 29, 521-530. [CrossRef]

95. Quintero, I.; Wiens, J.J. Rates of projected climate change dramatically exceed past rates of climatic niche evolution among vertebrate species. Ecol. Lett. 2013, 16, 1095-1103. [CrossRef]

96. Foden, W.B.; Butchart, S.H.M.; Stuart, S.N.; Vie, J.C.; Akçakaya, H.R.; Angulo, A.; DeVantier, L.M.; Gutsche, A.; Turak, E.; Cao, L.; et al. Identifying the World's Most Climate Change Vulnerable Species: A Systematic Trait-Based Assessment of all Birds, Amphibians and Corals. PLoS ONE 2013, 8, e65427. [CrossRef] [PubMed]

97. Carr, J.A.; Outhwaite, W.E.; Goodman, G.L.; Oldfield, T.E.E.; Foden, W.B. Vital but Vulnerable: Climate Change Vulnerability and Human Use of Wildlife in Africa's Albertine Rift; IUCN: Gland, Switzerland; Cambridge, UK, 2013.

98. Böhm, M.; Cook, D.; Ma, H.; Davidson, A.D.; García, A.; Tapley, B.; Pearce-Kelly, P.; Carr, J. Hot and bothered: Using trait-based approaches to assess climate change vulnerability in reptiles. Biol. Conserv. 2016, 204, 32-41. [CrossRef]

99. Ihlow, F.; Dambach, J.; Engler, J.O.; Flecks, M.; Hartmann, T.; Nekum, S.; Rajaei, H.; Rödder, D. On the brink of extinction? How climate change may affect global chelonian species richness and distribution. Glob. Chang. Biol. 2012, 18, 1520-1530. [CrossRef]

100. Waterson, A.M.; Schmidt, D.N.; Valdes, P.J.; Holroyd, P.A.; Nicholson, D.B.; Farnsworth, A.; Barrett, P.M. Modelling the climatic niche of turtles: A deep-time perspective. Proc. R. Soc. B Biol. Sci. 2016, 283, 20161408. [CrossRef] [PubMed]

101. Cunningham, H.R.; Rissler, L.J.; Buckley, L.B.; Urban, M.C. Abiotic and biotic constraints across reptile and amphibian ranges. Ecography 2016, 39, 1-8. [CrossRef]

102. Harsch, M.A.; HilleRisLambers, J. Climate Warming and Seasonal Precipitation Change Interact to Limit Species Distribution Shifts across Western North America. PLoS ONE 2016, 11, e0159184. [CrossRef] [PubMed]

103. Bates, A.E.; Pecl, G.T.; Frusher, S.; Hobday, A.J.; Wernberg, T.; Smale, D.A.; Sunday, J.M.; Hill, N.A.; Dulvy, N.K.; Colwell, R.K.; et al. Defining and observing stages of climate-mediated range shifts in marine systems. Glob. Environ. Chang. 2014, 26, 27-38. [CrossRef]

104. Rodrigues, J.F.M.; Lima-Ribeiro, M.S. Predicting where species could go: Climate is more important than dispersal for explaining the distribution of a South American turtle. Hydrobiologia 2018, 808, 343-352. [CrossRef] 
105. Hamilton, C.M.; Bateman, B.L.; Gorzo, J.M.; Reid, B.; Thogmartin, W.E.; Peery, M.Z.; Heglund, P.J.; Radeloff, V.C.; Pidgeon, A.M. Slow and steady wins the race? Future climate and land use change leaves the imperiled Blanding's turtle (Emydoidea blandingii) behind. Biol. Conserv. 2018, 222, 75-85. [CrossRef]

106. Iannella, M.; Cerasoli, F.; D’Alessandro, P.; Console, G.; Biondi, M. Coupling GIS spatial analysis and Ensemble Niche Modelling to investigate climate change-related threats to the Sicilian pond turtle Emys trinacris, an endangered species from the Mediterranean. PeerJ 2018, 6, e4969. [CrossRef]

107. Spinks, P.Q.; Pauly, G.B.; Crayon, J.J.; Shaffer, H.B. Survival of the western pond turtle (Emys marmorata) in an urban California environment. Biol. Conserv. 2003, 113, 257-267. [CrossRef]

108. Salas, E.A.L.; Seamster, V.A.; Harings, N.M.; Boykin, K.G.; Alvarez, G.; Dixon, K.W. Projected future bioclimate-envelope suitability for reptile and amphibian species of concern in south central USA. Herpetol. Conserv. Biol. 2017, 12, 522-547.

109. Butler, C.J.; Stanila, B.D.; Iverson, J.B.; Stone, P.A.; Bryson, M. Projected changes in climatic suitability for Kinosternon turtles by 2050 and 2070. Ecol. Evol. 2016, 6, 7690-7705. [CrossRef] [PubMed]

110. Spear, M.J.; Elgin, A.K.; Grey, E.K. Current and Projected Distribution of the Red-Eared Slider Turtle, Trachemys scripta elegans, in the Great Lakes Basin. Am. Midl. Nat. 2018, 179, 191-221. [CrossRef]

111. Witt, M.J.; Hawkes, L.A.; Godfrey, M.H.; Godley, B.; Broderick, A.C. Predicting the impacts of climate change on a globally distributed species: The case of the loggerhead turtle. J. Exp. Biol. 2010, 213, 901-911. [CrossRef] [PubMed]

112. Pike, D.A. Climate influences the global distribution of sea turtle nesting. Glob. Ecol. Biogeogr. 2013, 22, 555-566. [CrossRef]

113. Buhlmann, K.A.; Coffman, G. Fire ant predation of turtle nests and implications for the strategy of delayed emergence. J. Elisha Mitchell Sci. Soc. 2001, 117, 94-100.

114. Du Preez, L.H.; Badets, M.; Héritier, L.; Verneau, O. Tracking platyhelminth parasite diversity from freshwater turtles in French Guiana: First report of Neopolystoma Price, 1939 (Monogenea: Polystomatidae) with the description of three new species. Parasites Vectors 2017, 10, 53. [CrossRef]

115. Lever, C. Naturalized Reptiles and Amphibians of the World; Oxford University Press: New York, NY, USA, 2003.

116. Đorđević, S.; Anđelković, M. Possible reproduction of the red-eared slider, Trachemys scripta elegans (Reptilia: Testudines: Emydidae), in Serbia, under natural conditions. Hyla 2015, 2015, 44-49.

117. Micheli-Campbell, M.A.; Gordos, M.A.; Campbell, H.A.; Booth, D.T.; Franklin, C.E. The influence of daily temperature fluctuations during incubation upon the phenotype of a freshwater turtle. J. Zool. 2012, 288, 143-150. [CrossRef]

118. Pike, D.A. Forecasting the viability of sea turtle eggs in a warming world. Glob. Chang. Biol. 2014, $20,7-15$. [CrossRef] [PubMed]

119. Telemeco, R.S.; Abbott, K.C.; Janzen, F.J. Modeling the Effects of Climate Change-Induced Shifts in Reproductive Phenology on Temperature-Dependent Traits. Am. Nat. 2013, 181, 637-648. [CrossRef] [PubMed]

120. Fisher, L.R.; Godfrey, M.H.; Owens, D.W. Incubation Temperature Effects on Hatchling Performance in the Loggerhead Sea Turtle (Caretta caretta). PLoS ONE 2014, 9, e114880. [CrossRef] [PubMed]

121. Segura, L.N.; Cajade, R. The effects of sand temperature on pre-emergent green sea turtle hatchlings. Herpetol. Conserv. Biol. 2010, 5, 196-206.

122. Hays, G.C.; Mazaris, A.D.; Schofield, G.; Laloe, J.O. Population viability at extreme sex-ratio skews produced by temperature-dependent sex determination. Proc. R. Soc. B Biol. Sci. 2017, 284, 201962576. [CrossRef]

123. Howard, R.; Bell, I.; Pike, D.A. Tropical flatback turtle (Natator depressus) embryos are resilient to the heat of climate change. J. Exp. Biol. 2015, 218, 3330-3335. [CrossRef]

124. Montero, N.; Marcovaldi, M.A.G.D.; Lopez-Mendilaharsu, M.; Santos, A.S.; Santos, A.J.B.; Fuentes, M.M.P.B. Warmer and wetter conditions will reduce offspring production of hawksbill turtles in Brazil under climate change. PLoS ONE 2018, 13, e0204188. [CrossRef]

125. Saba, V.S.; Stock, C.A.; Spotila, J.R.; Paladino, F.V.; Tomillo, P.S. Projected response of an endangered marine turtle population to climate change. Nat. Clim. Chang. 2012, 2, 814-820. [CrossRef]

126. Dudley, P.N.; Bonazza, R.; Porter, W.P. Climate change impacts on nesting and internesting leatherback sea turtles using 3D animated computational fluid dynamics and finite volume heat transfer. Ecol. Model. 2016, 320, 231-240. [CrossRef] 
127. Dieng, H.B.; Cazenave, A.; Meyssignac, B.; Ablain, M. New estimate of the current rate of sea level rise from a sea level budget approach. Geophys. Res. Lett. 2017, 44, 3744-3751. [CrossRef]

128. Fish, M.R.; Côté, I.M.; Gill, J.A.; Jones, A.P.; Renshoff, S.; Watkinson, A.R. Predicting the Impact of Sea-Level Rise on Caribbean Sea Turtle Nesting Habitat. Conserv. Biol. 2005, 19, 482-491. [CrossRef]

129. Woodland, R.J.; Rowe, C.L.; Henry, P.F.P. Changes in Habitat Availability for Multiple Life Stages of Diamondback Terrapins (Malaclemys terrapin) in Chesapeake Bay in Response to Sea Level Rise. Chesap. Sci. 2017, 40, 1502-1515. [CrossRef]

130. Kraemer, J.E.; Bell, R. Rain-induced mortality of eggs and hatchlings of loggerhead sea turtles (Caretta caretta) on the Georgia Coast. Herpetologica 1980, 36, 72-77.

131. Foley, A.M.; Peck, S.A.; Harman, G.R. Effects of Sand Characteristics and Inundation on the Hatching Success of Loggerhead Sea Turtle (Caretta caretta) Clutches on Low-Relief Mangrove Islands in Southwest Florida. Chelonian Conserv. Biol. 2006, 5, 32-41. [CrossRef]

132. Tietjen, B.; Schlaepfer, D.R.; Bradford, J.B.; Hall, S.A.; Duniway, M.C.; Hochstrasser, T.; Jia, G.; Munson, S.M.; Pyke, D.A.; Wilson, S.D.; et al. Climate change-induced vegetation shifts lead to more ecological droughts despite projected rainfall increases in many global temperate drylands. Glob. Chang. Biol. 2017, 23, 2743-2754. [CrossRef] [PubMed]

133. Plummer, M.V.; Williams, B.K.; Skiver, M.M.; Carlyle, J.C. Effects of Dehydration on the Critical Thermal Maximum of the Desert Box Turtle (Terrapene ornata luteola). South Am. J. Herpetol. 2003, 37, 747-750. [CrossRef]

134. Bickford, D.; Howard, S.D.; Ng, D.J.J.; Sheridan, J.A. Impacts of climate change on the amphibians and reptiles of Southeast Asia. Biodivers. Conserv. 2010, 19, 1043-1062. [CrossRef]

135. Jergenson, A.M.; Miller, D.A.W.; Neuman-Lee, L.A.; Warner, D.A.; Janzen, F.J. Swimming against the tide: Resilience of a riverine turtle to recurrent extreme environmental events. Biol. Lett. 2014, 10, 20130782. [CrossRef]

136. Garcés-Restrepo, M.F.; Carr, J.L.; Giraldo, A. Long-Term Variation in Survival of a Neotropical Freshwater Turtle: Habitat and Climatic Influences. Diversity 2019, 11, 97. [CrossRef]

137. Hulin, V.; Delmas, V.; Girondot, M.; Godfrey, M.H.; Guillon, J.-M. Temperature-dependent sex determination and global change: Are some species at greater risk? Oecologia 2009, 160, 493-506. [CrossRef]

138. Neuwald, J.L.; Valenzuela, N. The Lesser Known Challenge of Climate Change: Thermal Variance and Sex-Reversal in Vertebrates with Temperature-Dependent Sex Determination. PLoS ONE 2011, 6, e18117. [CrossRef] [PubMed]

139. Valenzuela, N.; Literman, R.; Neuwald, J.L.; Mizoguchi, B.; Iverson, J.B.; Riley, J.L.; Litzgus, J.D. Extreme thermal fluctuations from climate change unexpectedly accelerate demographic collapse of vertebrates with temperature-dependent sex determination. Sci. Rep. 2019, 9, 4254. [CrossRef] [PubMed]

140. Kallimanis, A.S.; Kallimanis, A. Temperature dependent sex determination and climate change. Oikos 2010, 119, 197-200. [CrossRef]

141. Fuentes, M.; Hamann, M.; Limpus, C. Past, current and future thermal profiles of green turtle nesting grounds: Implications from climate change. J. Exp. Mar. Biol. Ecol. 2010, 383, 56-64. [CrossRef]

142. Wright, L.I.; Stokes, K.L.; Fuller, W.J.; Godley, B.J.; McGowan, A.; Snape, R.; Tregenza, T.; Broderick, A.C. Turtle mating patterns buffer against disruptive effects of climate change. Proc. R. Soc. B Biol. Sci. 2012, 279, 2122-2127. [CrossRef] [PubMed]

143. Fuentes, M.; Porter, W. Using a microclimate model to evaluate impacts of climate change on sea turtles. Ecol. Model. 2013, 251, 150-157. [CrossRef]

144. Mainwaring, M.C.; Barber, I.; Deeming, D.C.; Pike, D.A.; Roznik, E.A.; Hartley, I.R. Climate change and nesting behaviour in vertebrates: A review of the ecological threats and potential for adaptive responses. Biol. Rev. 2017, 92, 1991-2002. [CrossRef]

145. Refsnider, J.M.; Bodensteiner, B.L.; Reneker, J.L.; Janzen, F.J. Nest depth may not compensate for sex ratio skews caused by climate change in turtles. Anim. Conserv. 2013, 16, 481-490. [CrossRef]

146. Mazaris, A.D.; Kallimanis, A.S.; Pantis, J.D.; Hays, G.C. Phenological response of sea turtles to environmental variation across a species' northern range. Proc. R. Soc. B Biol. Sci. 2013, 280, 20122397. [CrossRef]

147. Weber, S.B.; Broderick, A.C.; Groothuis, T.G.; Ellick, J.; Godley, B.J.; Blount, J.D. Fine-scale thermal adaptation in a green turtle nesting population. Proc. R. Soc. B Biol. Sci. 2012, 279, 1077-1084. [CrossRef] 
148. Tilley, D.; Ball, S.; Ellick, J.; Godley, B.J.; Weber, N.; Weber, S.B.; Broderick, A.C. No evidence of fine scale thermal adaptation in green turtles. J. Exp. Mar. Biol. Ecol. 2019, 514, 110-117. [CrossRef]

149. Burrows, M.T.; Schoeman, D.S.; Buckley, L.B.; Moore, P.; Poloczanska, E.S.; Brander, K.M.; Brown, C.; Bruno, J.F.; Duarte, C.M.; Halpern, B.S.; et al. The Pace of Shifting Climate in Marine and Terrestrial Ecosystems. Science 2011, 334, 652-655. [CrossRef] [PubMed]

150. Chen, I.C.; Hill, J.K.; Ohlemuller, R.; Roy, D.B.; Thomas, C.D. Rapid Range Shifts of Species Associated with High Levels of Climate Warming. Science 2011, 333, 1024-1026. [CrossRef] [PubMed]

151. Hickey, S.M.; Phinn, S.R.; Callow, N.J.; Van Niel, K.P.; Hansen, J.E.; Duarte, C.M. Is Climate Change Shifting the Poleward Limit of Mangroves? Chesap. Sci. 2017, 40, 1215-1226. [CrossRef]

152. Lovelock, C.E.; Feller, I.C.; Reef, R.; Hickey, S.; Ball, M.C. Mangrove dieback during fluctuating sea levels. Sci. Rep. 2017, 7, 1680. [CrossRef] [PubMed]

153. Pielou, E.C. After the Ice Age: The Return of Life to Glaciated North America; University of Chicago Press: Chicago, IL, USA, 1991.

154. Davis, M.B. Climatic Instability, Time, Lags, and Community Disequilibrium. In Community Ecology; Diamond, J.M., Case, T.J., Eds.; Harper and Row: New York, NY, USA, 1984; pp. 269-284.

155. Sittaro, F.; Paquette, A.; Messier, C.; Nock, C.A. Tree range expansion in eastern North America fails to keep pace with climate warming at northern range limits. Glob. Chang. Biol. 2017, 23, 3292-3301. [CrossRef]

156. Butt, N.; Whiting, S.; Dethmers, K. Identifying future sea turtle conservation areas under climate change. Biol. Conserv. 2016, 204, 189-196. [CrossRef]

157. James, C.S.; Reside, A.E.; Vanderwal, J.; Pearson, R.G.; Burrows, D.; Capon, S.J.; Harwood, T.D.; Hodgson, L.; Waltham, N.J. Sink or swim? Potential for high faunal turnover in Australian rivers under climate change. J. Biogeogr. 2017, 44, 489-501. [CrossRef]

158. Cahill, A.E.; Aiello-Lammens, M.E.; Caitlin Fisher-Reid, M.; Hua, X.; Karanewsky, C.J.; Ryu, H.Y.; Sbeglia, G.C.; Spagnolo, F.; Waldron, J.B.; Wiens, J.J. Causes of warm-edge range limits: Systematic review, proximate factors and implications for climate change. J. Biogeogr. 2014, 41, 429-442. [CrossRef]

159. Stephens, P.R.; Wiens, J.J. Bridging the gap between community ecology and historical biogeography: Niche conservatism and community structure in emydid turtles. Mol. Ecol. 2009, 18, 4664-4679. [CrossRef]

160. Hutchison, V.H.; Vinegar, A.; Kosh, R.J. Critical thermal maxima in turtles. Herpetologica 1966, $22,32-41$.

161. Stralberg, D.; Carroll, C.; Pedlar, J.H.; Wilsey, C.B.; McKenney, D.W.; Nielsen, S.E. Macrorefugia for North American trees and songbirds: Climatic limiting factors and multi-scale topographic influences. Glob. Ecol. Biogeogr. 2018, 27, 690-703. [CrossRef]

162. Reside, A.E.; Critchell, K.; Crayn, D.M.; Goosem, M.; Goosem, S.; Hoskin, C.J.; Sydes, T.; Vanderduys, E.P.; Pressey, R.L. Beyond the Model: Expert Knowledge Improves Predictions of Species' Fates under Climate Change. Bull. Ecol. Soc. Am. 2019, 100, e01522. [CrossRef]

163. Rödder, D.; Schmidtlein, S.; Veith, M.; Lötters, S. Alien Invasive Slider Turtle in Unpredicted Habitat: A Matter of Niche Shift or of Predictors Studied? PLOS ONE 2009, 4, e7843. [CrossRef] [PubMed]

164. Chmura, H.E.; Glass, T.W.; Williams, C.T. Biologging physiological and ecological responses to climatic variation: New tools for the Climate Change Era. Front. Ecol. Evol. 2018, 6, 92. [CrossRef]

165. Litzgus, J.D.; Brooks, R.J.; Lee, J.R.E.; Costanzo, J.P. Phenology and ecology of hibernation in spotted turtles ( Clemmys guttata ) near the northern limit of their range. Can. J. Zool. 1999, 77, 1348-1357. [CrossRef]

166. Bacigalupe, L.D.; Opitz, T.; Lagos, N.A.; Timmermann, T.; Lardies, M.A.; Gaitán-Espitia, J.D. Geographic variation in thermal physiological performance of the intertidal crab Petrolisthes violaceus along a latitudinal gradient. J. Exp. Biol. 2014, 217, 4379-4386.

167. Heithaus, M.R.; McLash, J.J.; Frid, A.; Dill, L.M.; Marshall, G.J. Novel insights into green sea turtle behaviour using animal-borne video cameras. J. Mar. Biol. Assoc. UK 2002, 82, 1049-1050. [CrossRef]

168. Houghton, J.D.; Cedras, A.; Myers, A.E.; Liebsch, N.; Metcalfe, J.D.; Mortimer, J.A.; Hays, G.C. Measuring the state of consciousness in a free-living diving sea turtle. J. Exp. Mar. Biol. Ecol. 2008, 356, 115-120. [CrossRef]

169. Marshall, G.J. Crittercam: An animal-borne imaging and data logging system. Mar. Technol. Soc. J. 1998, 32, 11.

170. Myers, A.; Hays, G. Do leatherback turtles Dermochelys coriacea forage during the breeding season? A combination of data-logging devices provide new insights. Mar. Ecol. Prog. Ser. 2006, 322, 259-267. [CrossRef] 
171. Parlin, A.F.; do Amaral, J.P.S.; Dougherty, J.K.; Stevens, M.H.H.; Schaeffer, P.J. Thermoregulatory performance and habitat selection of the eastern box turtle (Terrapene carolina carolina). Conserv. Physiol. 2017, 5, 1-15. [CrossRef] [PubMed]

172. Hochscheid, S. Why we mind sea turtles' underwater business: A review on the study of diving behavior. J. Exp. Mar. Biol. Ecol. 2014, 450, 118-136. [CrossRef]

173. Fisher, R.A. The Genetical Theory of Natural Selection, 2nd ed.; Dover Books: New York, NY, USA, 1957.

174. Rees, A.; Alfaro-Shigueto, J.; Barata, P.; Bjorndal, K.; Bolten, A.; Bourjea, J.; Broderick, A.; Campbell, L.; Cardona, L.; Carreras, C.; et al. Review: Are we working towards global research priorities for management and conservation of sea turtles? Endanger. Species Res. 2016, 31, 337-382. [CrossRef]

175. Mrosovsky, N. Sex ratios of sea turtles. J. Exp. Zool. 1994, 270, 16-27. [CrossRef]

176. Gibbons, J.W. Sex ratios in turtles. Popul. Ecol. 1970, 12, 252-254. [CrossRef]

177. Laloë, J.O.; Cozens, J.; Renom, B.; Taxonera, A.; Hays, G.C. Effects of rising temperature on the viability of an important sea turtle rookery. Nat. Clim. Chang. 2014, 4, 513-518. [CrossRef]

178. Houghton, J.; Myers, A.; Lloyd, C.; King, R.; Isaacs, C.; Hays, G.; Hays, G. Protracted rainfall decreases temperature within leatherback turtle (Dermochelys coriacea) clutches in Grenada, West Indies: Ecological implications for a species displaying temperature dependent sex determination. J. Exp. Mar. Biol. Ecol. 2007, 345, 71-77. [CrossRef]

179. Chadwick, R.; Good, P.; Martin, G.; Rowell, D.P. Large rainfall changes consistently projected over substantial areas of tropical land. Nat. Clim. Chang. 2015, 6, 177-181. [CrossRef]

180. Gibbs, J.P.; Steen, D.A.; Bini, L.M.; Alexandre, J.; Diniz-Filho, F.; Carvalho, P.; Pinto, M.P.; Rangel, T.F.L.V.B.; Diniz-Filho, F. Trends in Sex Ratios of Turtles in the United States: Implications of Road Mortality. Conserv. Biol. 2005, 19, 552-556.

181. Bergmann, C. Über die Verhältnisse der Wärmeökonomie der Thiere zu ihrer Grösse. Göttinger Stud. 1847, 3, 595-708.

182. Meiri, S. Bergmann's Rule-What's in a name? Glob. Ecol. Biogeogr. 2011, 20, 203-207. [CrossRef]

183. Ashton, K.G.; Feldman, C.R. Bergmann's rule in nonavian reptiles: Turtles follow it, lizards and snakes reverse it. Evolution 2003, 57, 1151-1163. [CrossRef] [PubMed]

184. Iverson, J.B.; Smith, G.R. Reproductive Ecology of the Painted Turtle (Chrysemys picta) in the Nebraska Sandhills and across Its Range. Copeia 1993, 1993, 1-21. [CrossRef]

185. Werner, Y.L.; Korolker, N.; Sion, G.; Göçmen, B. Bergmann's and Rensch's rules and the spur-thighed tortoise (Testudo graeca). Biol. J. Linn. Soc. 2016, 117, 796-811. [CrossRef]

186. Lewis, E.L.; Iverson, J.B.; Smith, G.R.; Rettig, J.E. Body size and growth in the Red-eared Slider (Trachemys scripta elegans) at the northern edge of its range: Does Bergmann's rule apply? Herpetol. Conserv. Biol. 2018, 13, 700-710.

187. Sheridan, J.A.; Bickford, D. Shrinking body size as an ecological response to climate change. Nat. Clim. Chang. 2011, 1, 401-406. [CrossRef]

188. De Souza, R.R.; Vogt, R.C. Incubation temperature influences sex and hatchling size in the Neotropical turtle Podocnemis unifilis. J. Herpetol. 1994, 28, 453-464. [CrossRef]

189. Glen, F.; Broderick, A.; Godley, B.; Hays, G.; Godley, B.; Hays, G. Incubation environment affects phenotype of naturally incubated green turtle hatchlings. J. Mar. Biol. Assoc. UK 2003, 83, 1183-1186. [CrossRef]

190. Congdon, J.D.; Sels, R.C.V.L. Growth and body size in Blanding's turtles (Emydoidea blandingi): Relationships to reproduction. Can. J. Zool. 1991, 69, 239-245. [CrossRef]

191. Hirth, H.F. Some aspects of the nesting behavior and reproductive biology of sea turtles. Integr. Comp. Biol. 2015, 20, 507-523. [CrossRef]

192. Tucker, J.K.; Paukstis, G.L.; Janzen, F.J. Experimental analysis of an early life-history stage: Avian predation selects for larger body size of hatchling turtles. J. Evol. Biol. 2000, 13, 947-954.

193. Burke, V.J.; Standora, E.A.; Morreale, S.J. Factors Affecting Strandings of Cold-Stunned Juvenile Kemp's Ridley and Loggerhead Sea Turtles in Long Island, New York. Copeia 1991, 1991, 1136-1138. [CrossRef]

194. Griffin, L.P.; Griffin, C.R.; Finn, J.T.; Prescott, R.L.; Faherty, M.; Still, B.M.; Danylchuk, A.J. Warming seas increase cold-stunning events for Kemp's ridley sea turtles in the northwest Atlantic. PLoS ONE 2019, 14, e0211503. [CrossRef] [PubMed]

195. Jackson, J.B.C. Reefs since Columbus. Coral Reefs 1997, 16, S23-S32. [CrossRef] 
196. Mancini, A.; Koch, V.; Seminoff, J.A.; Madon, B. Small-scale gill-net fisheries cause massive green turtle Chelonia mydas mortality in Baja California Sur, Mexico. Oryx 2012, 46, 69-77. [CrossRef]

197. Wallace, B.P.; DiMatteo, A.D.; Bolten, A.B.; Chaloupka, M.Y.; Hutchinson, B.J.; Abreu-Grobois, F.A.; Mortimer, J.A.; Seminoff, J.A.; Amorocho, D.; Bjorndal, K.A.; et al. Global Conservation Priorities for Marine Turtles. PLoS ONE 2011, 6, e24510. [CrossRef] [PubMed]

198. Thomsen, P.F.; Willerslev, E. Environmental DNA-An emerging tool in conservation for monitoring past and present biodiversity. Biol. Conserv. 2015, 183, 4-18. [CrossRef]

199. Ficetola, G.F.; Miaud, C.; Pompanon, F.; Taberlet, P. Species detection using environmental DNA from water samples. Biol. Lett. 2008, 4, 423-425. [CrossRef]

200. Spear, S.F.; Groves, J.D.; Williams, L.A.; Waits, L.P. Using environmental DNA methods to improve detectability in a hellbender (Cryptobranchus alleganiensis) monitoring program. Biol. Conserv. 2015, 183, 38-45. [CrossRef]

201. Turner, C.R.; Uy, K.L.; Everhart, R.C. Fish environmental DNA is more concentrated in aquatic sediments than surface water. Biol. Conserv. 2015, 183, 93-102. [CrossRef]

202. Goldberg, C.S.; Pilliod, D.S.; Arkle, R.S.; Waits, L.P. Molecular Detection of Vertebrates in Stream Water: A Demonstration Using Rocky Mountain Tailed Frogs and Idaho Giant Salamanders. PLoS ONE 2011, 6, e22746. [CrossRef] [PubMed]

203. Davy, C.M.; Kidd, A.G.; Wilson, C.C. Development and Validation of Environmental DNA (eDNA) Markers for Detection of Freshwater Turtles. PLoS ONE 2015, 10, e0130965. [CrossRef] [PubMed]

204. García-Díaz, P.; Ramsey, D.S.L.; Woolnough, A.P.; Franch, M.; Llorente, G.A.; Montori, A.; Buenetxea, X.; Larrinaga, A.R.; Lasceve, M.; Álvarez, A.; et al. Challenges in confirming eradication success of invasive red-eared sliders. Biol. Invasions 2017, 19, 2739-2750. [CrossRef]

205. Urban, M.C.; Richardson, J.L.; Freidenfelds, N.A. Plasticity and genetic adaptation mediate amphibian and reptile responses to climate change. Evol. Appl. 2014, 7, 88-103. [CrossRef] [PubMed]

206. Fuentes, M.M.; Pike, D.A.; DiMatteo, A.; Wallace, B.P. Resilience of marine turtle regional management units to climate change. Glob. Chang. Biol. 2013, 19, 1399-1406. [CrossRef] [PubMed]

207. Newson, S.; Mendes, S.; Crick, H.; Dulvy, N.; Houghton, J.; Hays, G.; Hutson, A.; MacLeod, C.; Pierce, G.; Robinson, R. Indicators of the impact of climate change on migratory species. Endanger. Species Res. 2009, 7, 101-113. [CrossRef]

208. Patino-Martinez, J.; Marco, A.; Quiñones, L.; Hawkes, L. A potential tool to mitigate the impacts of climate change to the Caribbean leatherback sea turtle. Glob. Chang. Biol. 2012, 18, 401-411. [CrossRef]

209. Esteban, N.; Laloë, J.-O.; Kiggen, F.S.P.L.; Ubels, S.M.; Becking, L.E.; Meesters, E.H.; Berkel, J.; Hays, G.C.; Christianen, M.J.A. Optimism for mitigation of climate warming impacts for sea turtles through nest shading and relocation. Sci. Rep. 2018, 8, 17625. [CrossRef]

210. Hill, J.E.; Paladino, F.V.; Spotila, J.R.; Tomillo, P.S. Shading and Watering as a Tool to Mitigate the Impacts of Climate Change in Sea Turtle Nests. PLoS ONE 2015, 10, e0129528. [CrossRef]

211. Mitchell, N.J.; Janzen, F.J. Temperature-dependent sex determination and contemporary climate change. Sex. Dev. 2010, 4, 129-140. [CrossRef] [PubMed]

212. Fuentes, M.M.P.B.; Fish, M.R.; Maynard, J.A. Management strategies to mitigate the impacts of climate change on sea turtle's terrestrial reproductive phase. Mitig. Adapt. Strateg. Glob. Chang. 2012, 17, 51-63. [CrossRef]

213. Liles, M.J.; Peterson, T.R.; Seminoff, J.A.; Gaos, A.R.; Altamirano, E.; Henríquez, A.V.; Gadea, V.; Chavarría, S.; Urteaga, J.; Wallace, B.P.; et al. Potential limitations of behavioral plasticity and the role of egg relocation in climate change mitigation for a thermally sensitive endangered species. Ecol. Evol. 2019, 9, 1603-1622. [CrossRef] [PubMed] 
214. Diffenbaugh, N.S.; Field, C.B. Changes in Ecologically Critical Terrestrial Climate Conditions. Science 2013, 341, 486-492. [CrossRef] [PubMed]

215. Lavergne, S.; Mouquet, N.; Thuiller, W.; Ronce, O. Biodiversity and Climate Change: Integrating Evolutionary and Ecological Responses of Species and Communities. Annu. Rev. Ecol. Evol. Syst. 2010, 41, 321-350. [CrossRef] 